\title{
Trivalent $\mathrm{Cr}(\mathrm{III})$ and Hexavalent $\mathrm{Cr}(\mathrm{VI})$ Chromium Affect Morphology and Diversity of Hematopoietic Outcome in Japanese Quail (Coturnix Japonica)
}

\author{
Trivalent $\mathrm{Cr}(\mathrm{III})$ ve Hekzavalent $\mathrm{Cr}(\mathrm{VI})$ Krom iyonlarının Japon \\ Bıldırcınının (Coturnix Japonica) Morfolojisi ve Hematopoietik \\ Sonuçları Üzerine Etkisi
}

Research Article

Andi Alijagi, Damir Suljevi, Muhamed Focak

Department of Biology, Faculty of Science, University of Sarajevo, Zmaja od Bosne, Sarajevo, Bosnia and Herzegovina.

\section{A B STRACT}

\begin{abstract}
Chromium is a naturally occurring heavy metal found commonly in the environment in trivalent $\mathrm{Cr}$ (III) and hexavalent $\mathrm{Cr}(\mathrm{VI})$ forms. $\mathrm{Cr}(\mathrm{VI})$ compounds are rated as potential carcinogens. The study covered an analysis of the effect of $\mathrm{Cr}(\mathrm{III})$ as $\mathrm{CrCl}_{3}$ (chromium chloride) and $\mathrm{Cr}(\mathrm{VI})$ as $\mathrm{CrO}_{3}$ (chromium oxide) on hematological parameters of Japanese quail (Coturnix japonica). Chromium was added to food and water ad libitium and the experiment lasted 20 days. Significant differences in values of heterophils and lymphocytes were obtained with the tendency of reducing the number of these blood cells. The surface of erythrocytes, thrombocytes and heterophils was significantly reduced $(p<0.05)$. The Iymphocytes surface was significantly reduced $(p<0.05)$ during the application of $\mathrm{Cr}(\mathrm{VI})$ and increased ( $\mathrm{p}<0.05)$ when $\mathrm{Cr}(\mathrm{III})$ was administered. Chromium caused suppression of the immune system, reduced leucopoiesis and affected on microcytic anaemia development.
\end{abstract}

\section{Key Words}

Toxicity, chromium, quails, hematology.

\section{öz}

\begin{abstract}
Krom, üç değerlikli $\mathrm{Cr}(\mathrm{III})$ ve altı değerlikli $\mathrm{Cr}(\mathrm{VI})$ formlarında yaygın olarak bulunan, doğal olarak oluşan I bir ağır metaldir. Cr(VI) bileşikleri potansiyel kanserojenler olarak sınıflandırılmıştır. Çalışma, Japon bıldırcınlarının (Coturnix japonica) hematolojik parametrelerinde $\mathrm{Cr}$ (III)'ün $\mathrm{CrCl}_{3}$ (krom klorür) ve $\mathrm{Cr}(\mathrm{VI}$ )'nın $\mathrm{CrO}_{3}$ (krom oksit) olarak etkisinin analizini kapsamaktadır. Krom yiyeceklere ve içeceklere ilave edilmiş ve deneyler 20 gün boyunca sürdürülmüştür. Kan hücrelerinin sayısında azalma eğilimi ile heterofiller ve lenfosit değerlerinde belirgin farklılıklar elde edilmiştir. Eritrositlerin, trombositlerin ve heterofillerin yüzeyi önemli derecede küçülmüştür (p<0.05). Lenfosit yüzeyi, $\mathrm{Cr}(\mathrm{VI})$ uygulaması sırasında önemli ölçüde küçülmüş ( $p<0.05), C r(I I I)$ uygulandığında ise artmıştır. ( $p<0.05)$. Krom, bağışıklık sisteminin baskılanmasına, Iökopoezin azalmasına ve mikrositer anemi gelişimine neden olmuştur.
\end{abstract}

\section{Anahtar Kelimeler}

Toksisite, krom, bıldırcın, hematoloji.

Article History: Received: Sep 5, 2016; Revised: Oct 10, 2016; Accepted: Jan 15, 2017; Available Online: Apr 1, 2017. DOI: $10.15671 /$ HJBC.2017.161

Correspondence to: A. Alijagi, Department of Biology, Faculty of Science, University of Sarajevo, Zmaja od Bosne, Sarajevo, Bosnia and Herzegovina. 


\section{INTRODUCTION}

Lexavalent chromium is extremely toxic substance, but for trivalent chromium still stays unresolved is it safe or not. Numerous studies showed that trivalent chromium potentially affects the development of certain pathological conditions and diseases in human or animal organisms. However, some studies showed that it has effects on activation of the immune system, as well as the impact on the animal development [1]. Many studies confirmed that trivalent chromium has a beneficial effect on insulin signalling $[2,3]$ and if the mechanisms described is accurate, trivalent chromium in the future will be very important in the treatment of diabetes. Based on the results of animal studies where animals were exposed to long-term oral intake of trivalent chromium (chromium acetate, chromium chloride, chromium nicotinate, chromium oxide, chromium picolinate) it can not be clearly distinguished whether these derivatives have the same effect on the gastrointestinal system, liver, kidneys, cardiovascular system, endocrine system or hematological parameters [4-8]. Other studies indicate toxic effects of trivalent chromium, the formation of different reactive oxygen radicals (ROS), which consequently alter the structure of DNA and cellular proteins and cause development of cell stress, which ultimately causes cell death [8-11].

Smallest amount of hexavalent chromium is considered as toxic according to WHO [12] Hexavalent chromium affects on the development of microcytic and hypochromic anemia and also on the emergence of numerous developmental defects, it directly affects reproduction, changing the properties of the gonads in both sexes, reduces the number of live births of cubs, disturbs the length of estrus, causing disturbances in the sexual behavior, changing values of the majority of biochemical parameters and causes severe gastrointestinal disturbances [4]. There is not enough information about the chromium effects on blood cells of Japanese quail, as well as other animals and for this reason, the present study was conducted. Thus, the main objective of this study was to observe effects of chromium derivates on leukocyte number and size and as the model animal in this study was used japanese quail.

\section{MATERIALS and METHODS}

\section{Breeding}

All animals used in this study came from artificial breeding (Sarajevo, Bosnia and Herzegovina). Breeding was carried out according to standard procedures and the optimal conditions. Euthanasia and all procedures with animals were conducted in accordance to Directive 2010/63/EU of the European Parliament and of the Council of 22 September 2010 on the protection of animals used for scientific purposes.

\section{Experimental Design}

After 37 days of age, individuals were separated into cages with the dimensions $120 \times 80 \times 60 \mathrm{~cm}$ (with a balanced relation between the sexes). Quails were divided into three groups: group I (control group, 12 individuals); Group || (12 individuals treated with chromium-3-chloride and group III (12 individuals treated with chromium3-oxide). The temperature in the room with the cages was maintained in the range of $23-27^{\circ} \mathrm{C}$ with 16 hours of daylight. Access to food and water was adlibitium. All specimens had the identical diet consisting of corn grits (control group), with the addition of chromium products in food and water in the experimental group ( $1 \mathrm{mg} / \mathrm{L}$ of water or 1 $\mathrm{mg} / \mathrm{kg}$ of food). The experiment lasted 20 days (Laboratory of Physiology, Faculty of Science, Sarajevo, Bosnia and Herzegovina). After the experiment, one milliliter of blood was collected for analysis by the veni-punctuation of the jugular vein using insulin syringes (Medoject, Slovakia) without anticoagulants.

\section{Staining and Microscopical Analysis}

For the microscopical analysis of blood, the blood smears were made and stained by May-GrunwaldGiemsa (Semikem, BiH). Staining and analysis of blood cells were performed using the standard method for the differential blood count. The surface of blood cells was analysed using a DP Olympus software, based on photomicrographs taken with a special camera directly connected to the microscope Olympus DP12 Digital Microscope. 


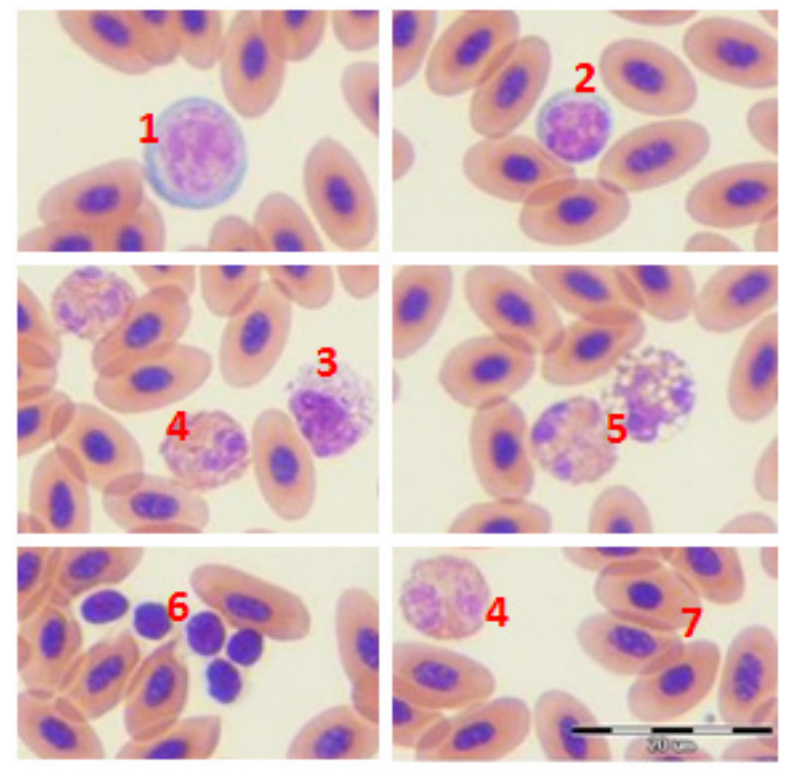

Figure 1. Hematological cells of japanese quail (Coturnix japonica): 1. monocyte; 2. Iymphocyte; 3,4,5. heterophils; 6. aggregation of thrombocytes; 7 . cluster of erythrocytes; magnification bar-20 $\mu \mathrm{m}$.

Table 1. Differential blood count of japanese quail (Coturnix japonica) treated with chromium chloride and chromium oxide.

\begin{tabular}{cccccccc}
\hline \multirow{2}{*}{ Parameter } & \multicolumn{2}{c}{ Group I } & \multicolumn{2}{c}{ Group I } & \multicolumn{2}{c}{ Group I } & p-value \\
\cline { 2 - 6 } & mean \pm SD & range & mean \pm SD & range & mean \pm SD & Range & \\
\hline Heterophils & $0.278 \pm 0.08^{\text {b }}$ & $0.14-0.42$ & $0.527 \pm 0.09^{\text {a }}$ & $0.66-0.35$ & $0.312 \pm 0.16^{\text {b }}$ & $0.12-0.71$ & 0.00. \\
\hline Eosinophils & 0.01 & $\leq 0.01$ & 0.01 & $\leq 0.01$ & 0.01 & $\leq 0.01$ & n.s. \\
\hline Basophils & 0.01 & $\leq 0.01$ & 0.01 & $\leq 0.01$ & 0.01 & $\leq 0.01$ & n.s. \\
\hline Monocytes & 0.01 & $\leq 0.01$ & 0.012 & $0.01-0.02$ & 0.01 & $\leq 0.01$ & n.s. \\
\hline Lymphocytes & $0.717 \pm 0.08^{\text {b }}$ & $0.58^{-}$ & $0.465 \pm 0.09^{a}$ & $0.31-0.61$ & $0.683 \pm 0.17^{\text {b }}$ & $0.28-0.88$ & 0.00. \\
\hline
\end{tabular}

Table 2. Average surface values of hematological cells in japanese quail (Coturnix japonica).

\begin{tabular}{|c|c|c|c|c|c|c|c|}
\hline \multirow{2}{*}{ Parameter } & \multicolumn{2}{|c|}{ Group I } & \multicolumn{2}{|c|}{ Group I } & \multicolumn{2}{|c|}{ Group I } & \multirow{2}{*}{$p$-value } \\
\hline & mean $\pm S D$ & range & mean $\pm S D$ & range & mean $\pm S D$ & Range & \\
\hline Erythrocytes & $61.24 \pm 1.71^{\mathrm{a}}$ & $\begin{array}{l}58.77^{-} \\
63.28\end{array}$ & $57.15 \pm 3.45^{b}$ & $\begin{array}{l}51.98- \\
63.22\end{array}$ & $56.01 \pm 3.23^{b}$ & $\begin{array}{l}51.90- \\
61.71\end{array}$ & 0.00 \\
\hline Thrombocytes & $12.49 \pm 0.91^{a}$ & $\begin{array}{l}10.65- \\
13.66\end{array}$ & $11.23 \pm 0.91^{b}$ & $\begin{array}{c}9.63- \\
12.99\end{array}$ & $8.77 \pm 1.12^{\mathrm{c}}$ & $\begin{array}{c}7.29- \\
10.67\end{array}$ & 0.00 \\
\hline Monocytes & $67.38 \pm 4.59^{a}$ & $\begin{array}{l}59.29- \\
71.23\end{array}$ & $71.44 \pm 6.93^{a}$ & $\begin{array}{l}65.13- \\
82.53\end{array}$ & $77.51 \pm 11.8^{a}$ & $\begin{array}{l}60.16- \\
93.71\end{array}$ & 0.03 \\
\hline Heterophils & $63.72 \pm 2.35^{\mathrm{a}}$ & $\begin{array}{l}60.14- \\
66.68\end{array}$ & $63.80 \pm 2.63^{a}$ & $\begin{array}{l}60.64- \\
70.23\end{array}$ & $50.40 \pm 10.7^{b}$ & $\begin{array}{l}31.51- \\
69.89\end{array}$ & 0.00 \\
\hline Lymphocytes & $35.27 \pm 6.53^{b}$ & $\begin{array}{l}27.35- \\
44.37\end{array}$ & $43.34 \pm 6.96^{a}$ & $\begin{array}{l}30.37- \\
52.31\end{array}$ & $31.32 \pm 6.62^{b}$ & $\begin{array}{l}23.39- \\
44.54\end{array}$ & 0.00 \\
\hline Eosinophils & $57.11 \pm 3.86$ & $\begin{array}{l}52.27- \\
61.23\end{array}$ & $59.01 \pm 2.57$ & $\begin{array}{l}55.62- \\
61.23\end{array}$ & $58.27 \pm 4.58$ & $\begin{array}{l}52.10- \\
61.23\end{array}$ & 0.467 \\
\hline Basophils & $60.99 \pm 1.34$ & $\begin{array}{l}59.30- \\
62.39\end{array}$ & $61.31 \pm 2.8^{7}$ & $\begin{array}{l}57.85^{-} \\
64.58\end{array}$ & $61.05 \pm 2.13$ & $\begin{array}{l}58.80^{-} \\
63.74\end{array}$ & 0.934 \\
\hline
\end{tabular}




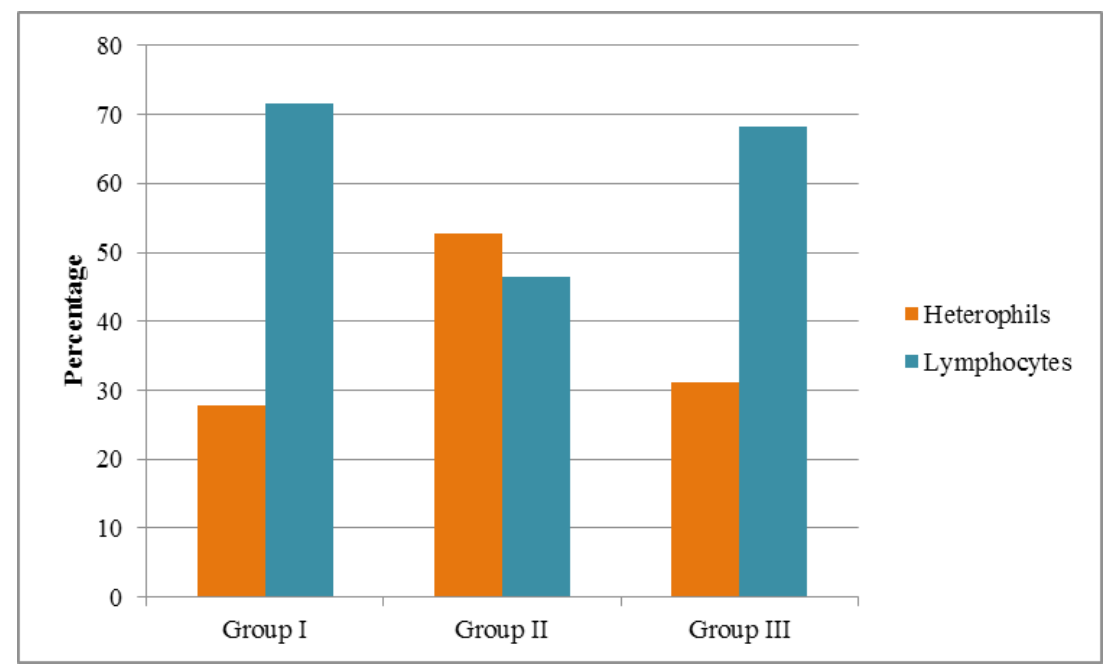

Figure 2. Occurrence of lymphocytes and heterophils in control (group I) and chromium treatments (group II-trivalent and group III-hexavalent).

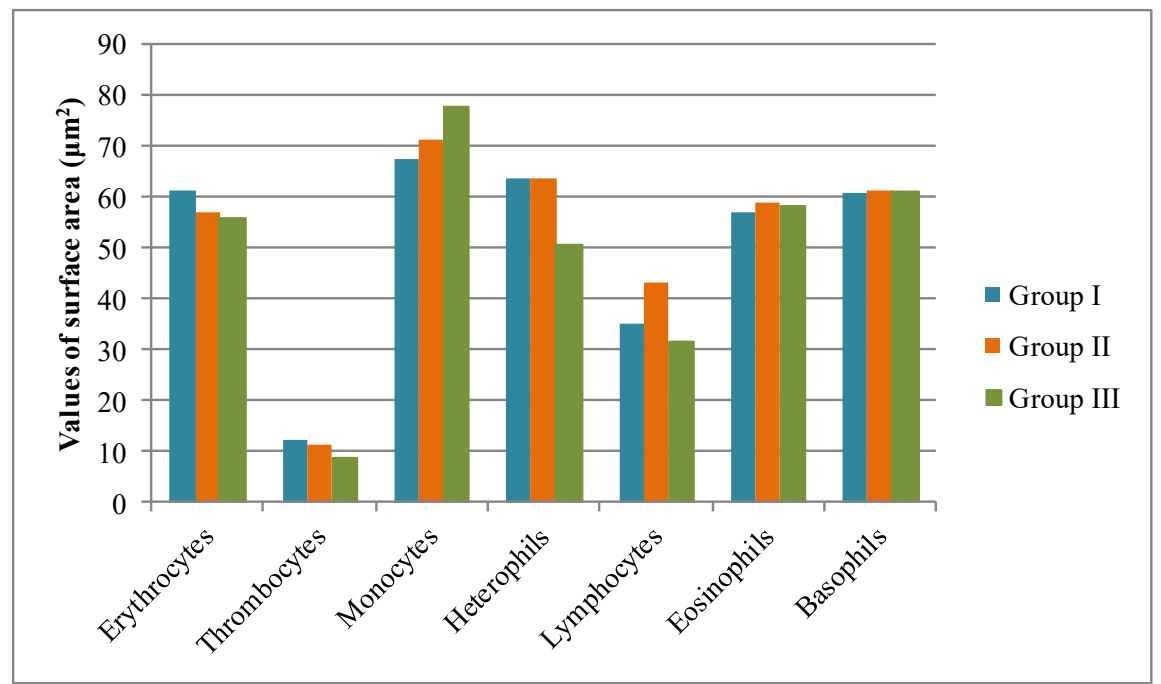

Figure 3. Comparison of cell surface values between control (group I) and chromium treatments (group II-trivalent and group III-hexavalent).

\section{Statistical Analysis}

The values of the surface and the number of blood cells were statistically analysed using the IBM SPSS Statistics (v. 20; SPSS, Inc., Chicago, IL, USA). Differences between groups were obtained using ANOVA and Tukey posthoc test. $P$ values lower than $0.05(p<0.05)$ considered significant.

\section{RESULTS}

Different and the most numerous types of leukocytes in japanese quail observed in this study are showed in Figure 1.
Table 1, presents the values of the blood cells number in japanese quail treated with derivatives of trivalent and hexavalent chromium.

Heterophils and lymphocytes were the most abundant cells with most obvious intergroup differences (Figure 2), while basophils, monocytes and eosinophils were rarest cells.

Table 2, presents the values of blood cells surface of all three groups of quails. Comparison of mean cell area values between groups is presented in Figure 3, Significant differences 
between these groups $(p<0.05)$ were obtained for erythrocytes, thrombocytes, lymphocytes, monocytes and heterophils except for eosinophils and basophils.

The surface of red blood cells, thrombocytes and heterophils showed the significant reduction ( $p<0.05)$ starting from a group I to group III. Different intergroup values for erythrocytes, thrombocytes and heterophils surface were the result of significant differences in both experimental groups compared to the values obtained in the control group $(p<0.05)$. The group treated with hexavalent chromium had the significantly smaller surface of lymphocytes in comparison to control group ( $p<0.05)$. Monocytes also showed significant differences between groups ( $p<0.05)$.

\section{DISCUSSION}

Our research reveals that trivalent and hexavalent chromium lead, mainly, to a reduction of the erythrocyte surface. If we analyse the surface of other blood cells, it can be concluded that hexavalent chromium in addition to the size of erythrocytes affects on the reduction of the surface of thrombocytes and heterophils $(p<0.05)$ $\mathrm{Cr}$ (III) lead to the reduction of erythrocytes, thrombocytes and heterophils, while an area of lymphocytes was increased ( $p<0.05)$. Mechanisms of chromium effects on basophils, eosinophil and monocytes can not be considered positive or negative, because of their small number in peripheral blood and variable cell size. Reduction of the most blood cells surface can be attributed to hexavalent chromium while trivalent chromium did not have only that effect. Trivalent chromium was responsible for a growth of lymphocytes. According to some studies, $\mathrm{Cr}^{3+}$ and $\mathrm{Cr}^{6+}$ affect on these changes by a production of reactive oxygen species (ROS) [13]. Hexavalent chromium that enters in cells under physiological conditions can be reduced by hydrogen peroxide $\left(\mathrm{H}_{2} \mathrm{O}_{2}\right)$, glutathione (GSH) reductase, and ascorbic acid (vitamin C) to produce reactive intermediates including $\mathrm{Cr}^{5+}, \mathrm{Cr}^{4+}$, thiol radicals, hydroxyl radicals and at the end of reduction chain $\mathrm{Cr}^{3+}$ [14]. Any of these compounds could attack DNA, proteins, and membrane lipids, thereby disrupting cellular integrity and functions [13]. Reduction of erythrocyte area is expected due to the facts about reactions between chromium and hemoglobin molecule. Cases of hematological effects have been reported in humans after the ingestion of lethal or sublethal doses of $\mathrm{Cr}^{6+}$. In a case of the woman who ingested a few grammes of potassium dichromate, decreased hemoglobin content and hematocrit, increased total white blood cell counts, reticulocyte counts, and plasma hemoglobin were found four days after ingestion. These effects were indicative of intravascular hemolysis $[15,16]$. Because of similar values in the number of erythrocytes in II and III group of japanese quails, this is the first research which reveals the influence of $\mathrm{Cr}^{3+}$ and $\mathrm{Cr}^{6+}$ on the development of microcytic anaemia. The decrease of thrombocyte surface can lead to the decrease of their activity which can be reflected in any segment of hemostasis. Analysis of a total number of leukocytes showed the significant influence of both chromium derivates on values of differential blood count. It is important to emphasise the fact that both chromium derivates induce decreasing of lymphocytes ( $p<0.05)$ [17] and increasing of heterophils $(p<0.05)$ in total leukocyte number. Recent studies did not show these findings. The effects of $\mathrm{Cr}^{3+}$ and $\mathrm{Cr}^{6+}$ lead to suppression of immune system which results with reduced leukopoiesis [18], especially with decreasing of lymphocyte number but increasing their surface. $\mathrm{Cr}^{6+}$ in lower concentration shows the bi-phase effect in hytohemeagglutinininduced blastogenesis in human lymphocytes showed inhibition of lymphocyte proliferation of T-cells by using CoCrMo [19-22]. When comparing number and size of cells, effect of $\mathrm{Cr}^{6+}$ has evident effects on the cell surface. On the other hand, after 20 days, trivalent chromium causes a change of leukocyte number, with an assumption that longer exposure would lead to the total reduction of leukocytes. Real effects of trivalent and hexavalent chromium are in direct correlation with their solubility and precipitation affinities in different blood cell types, especially in erythrocytes.

Significant differences in values of heterophils and lymphocytes were obtained with the tendency of reducing the number of these blood cells. The 
surface of red blood cells, thrombocytes and heterophils were significantly reduced. The area of lymphocytes surface was significantly reduced during the application of $\mathrm{Cr}(\mathrm{VI})$ and increased when $\mathrm{Cr}$ (III) was administered. Chromium causes suppression of the immune system, reducing leucopoiesis and affected on microcytic anaemia development.

\section{References}

1. A. Yildiz, S. Parlat, O. Yazgan, The effects of organic chromium supplementation on production traits and some serum parameters of laying, Quails. Rev. Med. Vet., 155 (2004) 642.

2. N. Kleefstra, H. Bilo, S. Bakker, S. Houweling, Chroom en insulineresistentie, Ned. Tijdschr. Geneeskd., 148 (2004) 217.

3. J. Vincent, Recent advances in the nutritional biochemistry of trivalent chromium, Proc.Nutr. Soc., 63 (2004) 41.

4. R. Anderson, M. Polansky, N. Bryden, K. Patterson, C. Veillon, W. Glinsmann, Effects of chromium supplementation on urinary $\mathrm{Cr}$ excretion of human subjects and correlation of $\mathrm{Cr}$ excretion with selected clinical parameters, J. Nutr., 113 (1983) 276.

5. P. Sakas, Essentials of Avian Medicine: A Practitioner's Guide 2nd Edition, AAHA Press., (2002).

6. E. Hernawan, S. Wahyuni, H. Suprapti, The levels of blood glucose, trygliceride, final body weight and abdominal fat percentage of broiler under sexseparated and straight run rearing system, Lucr ri Ştiin ifice-Seria Zootehnie, 57 (2012) 28.

7. S. Ukashatu, A. Bello, M. Umaru, J. Onu, A. Shehu, A. Mahmuda, B. Saidu, A study of some serum biochemical values of Japanese quails (Coturnix coturnix japonica) fed graded levels of energy diets in Northwestern Nigeria, Sci. J. Micro., 3 (2014) 1.

8. R. Sokoll, M. Gesek, M. Ras-Norynska, M. Michalczyk, S. Koziatek, Biochemical parameters in Japanese quails Coturnix coturnix japonica infected with coccidia and treated with Toltrazuril, Pol. J. Vet. Sci., 18 (2015) 79.

9. T. Ozawa, A. Hanaki, Spin-trapping studies on the reactions of $\mathrm{Cr}(\mathrm{III})$ with hydrogen peroxide in the presence of biological reductants: is $\mathrm{Cr}(\mathrm{III})$ non-toxic? Int. J. Biochem., 22 (1990) 343.
10. I. Kat, J. Vogelman, V. Dilman, J. Karkoszka, K. Frenkel, N. Durr, P. Toniolo, Effect of supplementation with chromium picolinate on antibody titers to 5hydroxymethyl uracil, Eur. J. Epidemiol., 14 (1998) 621

11. N. Tonks, PTP1B: From the sidelines to the front lines! FEBS, Letters, 546 (2003) 140.

12. A. Dayan, A. Paine, Mechanisms of chromium toxicity, carcinogenicity and allerginicity: Review of the literature from 1985 to 2000, Hum. Exp. Toxicol., 20 (2001) 439.

13. G. De Mattia, M.C. Bravi, O. Laurenti, O. De Luca, A. Palmeri, A. Sabatucci, G. Mendico, A. Ghiselli, Impairment of cell and plasma redox state in subjects professionally exposed to chromium, Am. J. Ind. Med., 46 (2004) 120.

14. K. Sugden, D. Stearns, The role of chromium (V) in the mechanism of chromate-induced oxidative DNA damage and cancer, J. Environ. Pathol. Toxicol. Oncol., 19 (1999) 215.

15. B.K. Sharma, P.C. Singhal, K.S. Chugh, Intravascular haemolysis and acute renal failure following potassium dichromate poisoning, Postgrad. Med. J., 54 (1978) 414

16. Y. Loubieres, A. de Lassence, M. Bernier, A. VieillardBaron, J. M. Schmitt, B. Page, F. Jardin, Acute, fatal, oral chromic acid poisoning, J. Toxicol. Clin. Toxicol., 37 (1999) 333.

17. M. Myslak, K. Kosmider, Kinetics of cell division in peripheral blood lymphocytes of stainless steel welders, Medycyna Pracy, 48 (1997) 261.

18. S. Richa, R.K. Upreti, P.K. Seth, U.C. Chaturvedi, Effects of chromium on the immune system, FEMS Immunol. Med. Microbiol., 34 (2002) 1.

19. P. Borella, S. Manni, A. Giardino, Cadmium, nickel, chromium and lead accumulate in human lymphocytes and interfere with PHA-induced proliferation. Journal of trace elements and electrolytes in health and disease, J. Trace. Elem. Electrolytes. Health. Dis. 4 (1990) 87.

20. C. Faleiro, I. Godinho, U. Reus, M. de Sousa, Cobaltchromium-molybdenum but not titanium-6aluminium4 vanadium al-loy discs inhibit human T cell activation in vitro, Biometals, 9 (1996) 321.

21. J.Y. Wang, B.H. Wicklund, R.B. Gustilo, D.T. Tsukayama, Prosthetic metals impair murine immune response and cytokine release in vivo and in vitro, J. Orthop. Res., 15 (1997) 688.

22. B. Yucesoy, S. Mirshahidi, C. Yucesoy, A. Karakaya, In vitro effects of various metals on natural killer cell activity in cultured human lymphocytes. Immunopharmacol. Immunotoxicol., 21 (1999) 599. 